\title{
International Common Law: The Soft Law of International Tribunals
}

\author{
Andrew T. Guzman* and Timothy L. Meyer**
}

\section{INTRODUCTION}

The dominant trend in international law since the end of the Second World War has been one of increasing legalization. ${ }^{1}$ States have created legal regimes of one form or another to govern a host of areas previously left to the realm of politics. Not surprisingly, this rising tide of legalization has confronted states with the problem of designing legal mechanisms to address heretofore political problems. But states can be innovative, and the novel application of legal solutions to political problems has led to a proliferation of new or rarely used forms of international law. States have expanded the use of international organizations, ${ }^{2}$ created international tribunals with jurisdiction over a range of both state and individual conduct, ${ }^{3}$ and employed soft law to establish rules in a wide range of issue areas. ${ }^{4}$

* Professor of Law, Berkeley Law School.

** Fellow, Public Policy and Nuclear Threats Program, University of California Institute for Global Conflict and Cooperation.

1 See generally, for example, Beth A. Simmons, The Legalization of International Monetary Affairs, 54 Intl Org 573 (2000).

2 See generally, for example, Duncan B. Hollis, Why State Consent Still Matters: Non-State Actors, Treaties, and the Changing Sources of International Law, 23 Berkeley J Intl L 137 (2005) (discussing the "proliferation of international rules, processes, and organizations").

3 See, for example, Laurence R. Helfer and Anne-Marie Slaughter, Why States Create International Tribunals: A Response to Professors Posner and Yoo, 93 Cal L Rev 899, 910 (2005) ("Within the past decade, the world has witnessed an explosion of international adjudication."); Chester Brown, The Proliferation of Intermational Courts and Tribunals: Finding Your Way Through the Maze, 3 Melb J Intl L 453, 454 (2002) ("The establishment of new fora for third party dispute settlement is undoubtedly one of the more striking international legal developments in recent years.').

4 See generally, for example, Timothy Meyer, Soft Law as Delegation, 32 Fordham Intl L J _(forthcoming 2009), available online at <http://ssm.com/abstract $=1214422>$ (visited Dec 5, 2008) (discussing examples of soft-law regimes). 
The subject of this Article lies at the intersection of two institutions states have used during this period of legalization: international tribunals and soft law. We argue that the nature of channeling legal disputes to international tribunals necessarily implicates the use of soft law. In short, decisions of international tribunals interpret binding legal obligations but are not themselves legally binding beyond the particular states and the particular facts before the tribunal. Any further role performed by these decisions is best characterized as soft law. Tribunal rulings can nevertheless influence state behavior by implicating a state's reputation for compliance with international law, by bolstering the reciprocity underlying an agreement, or by triggering retaliation. ${ }^{5}$ Moreover, by establishing a tribunal to interpret legal obligations in a way that gives rise to a soft-law jurisprudence, states are able to expand the tribunal's influence beyond those states that submit to the tribunal's jurisdiction. In effect, all states subject to the underlying legal obligation come to be subject to the soft-law impact of the tribunal, regardless of whether they have formally submitted to the tribunal's jurisdiction. In sum, the decisions of international tribunals create a form of nonbinding, yet influential, international common law.

This argument is perhaps counterintuitive. Generally, a tribunal's decisions are thought to be either legally binding or not. But even when a ruling is binding, its impact is quite circumscribed. The decisions of the UN Human Rights Committee ("Committee"), for example, do not carry the force of law at alleven with respect to the dispute at issue. The decisions of the International Court of Justice ("ICJ"), on the other hand, are considered binding on the parties to the dispute. The ICJ ruling, however, is binding only on the parties before it and only with respect to the particular case at issue. ${ }^{6}$ In other words, there is no rule of stare decisis at the ICJ. Thus, while a ruling from the ICJ represents a legally binding resolution of the dispute, it carries the force of law in only a very narrow sense.

Of course, the fact that a tribunal's rulings are binding only on the parties before it does not mean that those rulings have no influence on other states' legal expectations. There is no doubt that international tribunals' decisions signal the direction of future rulings and, de facto, define the contours of the legal obligations states face. In the absence of stare decisis these rulings can only be

5 These mechanisms-reputation, reciprocity, and retaliation-are referred to as the "Three Rs of Compliance." See Andrew Guzman, How International Law Works: A Rational Choice Theory 33-48 (Oxford 2008).

6 Statute of the International Court of Justice (1945), art 59, I1, 59 Stat 1031 ("The decision of the Court has no binding force except between the parties and in respect of that particular case.'). 
described as a form of soft law. ${ }^{7}$ That is, they do not formally determine the content of a binding legal obligation. Instead, they are nonbinding interpretations of hard legal obligations. As such, they shape states' expectations and implicate states' reputations for compliance with international law, and so can constrain states' behavior.

Using soft law in this way allows states to avoid the normal requirement of state consent. Most obviously, a tribunal's ruling influences other states that may find themselves before that tribunal. Each ruling provides information about how the tribunal is likely to rule in the future, and states can adjust their behavior to take that information into account. To the extent that a ruling has an impact, neither the parties to the dispute nor other parties subject to the tribunal's jurisdiction have the power to nullify the ruling. ${ }^{8}$ But a tribunal can influence a broader set of states as well. A tribunal opines on some set of substantive legal rules, and its rulings affect the expectations and beliefs of states. For this reason, a tribunal's rulings influence the legal obligations held by all states-including those that are not subject to the tribunal's jurisdiction. Thus, the influence of an international tribunal extends to states that choose not to submit to the tribunal's jurisdiction. In effect, the grant of jurisdiction to a tribunal acts as a delegation of power to craft soft legal norms interpreting an underlying binding legal obligation. States can, of course, always choose not to submit themselves to the jurisdiction of international tribunals. Often, a jurisdictional grant is appended as an optional protocol to a treaty so states can sign the treaty without agreeing to the dispute-resolution provision. But a state's refusal to submit to the jurisdiction of a tribunal does not free that state from the influence of the tribunal's decisions interpreting the treaty. Although the decisions are binding only on states before the tribunal, the tribunal's jurisprudence forms a type of soft law that piggybacks on the hard legal obligations, and constrains all states subject to the underlying binding legal obligation.

This Article proceeds in four parts, including this introduction. Section II defines what we mean by soft law and lays out a theory explaining why states would choose to delegate to international tribunals the ability to make soft law. Section III explores the theory in the context of the UN Human Rights Committee. The Committee, whose jurisdiction is controlled by an Optional Protocol to the International Covenant on Civil and Political Rights ("ICCPR"), lacks the power to issue binding rulings interpreting states' obligations under the

7 Where the rulings are nonbinding even with respect to the particular dispute, that aspect of the tribunal's role is also soft law.

8 States could presumably nullify a ruling through a unanimous agreement to do so, but this is obviously a demanding requirement that will normally not be possible. 
ICCPR. Its rulings interpreting the binding obligations contained in the ICCPR are thus a form of soft law that influences not only states that have signed the Optional Protocol, but all states subject to the ICCPR. Section IV concludes.

\section{THEORIES OF SOFT LAW}

\section{A. SOFT LAw DEFINED}

A threshold issue that must be resolved is the precise meaning of the term "soft law." Soft law is defined differently by different scholars and these alternative definitions can create confusion-something we hope to avoid. Some writers refer to soft law as an instrument that creates imprecise obligations under which a wide range of activity might be considered compliant. ${ }^{9}$ Other scholars define soft law as those instruments that impose merely hortatory, rather than legally binding, obligations. ${ }^{10}$ The latter definition focuses on a doctrinal distinction between whether an obligation is legally binding at the international level; the former focuses not on doctrine, but on the degree to which an obligation narrows the range of compliant behavior. Neither of these definitions can claim to be correct in any objective sense, but as they are different it is important to be clear about which is being used.

This Article defines soft law consistently with the second definition (for example, nonbinding instruments), though it includes in the definition statements about legal rules that go beyond explicit agreements among states. Soft law, as the term is used in this Article, refers broadly to quasi-legal rules that are not legally binding on states. ${ }^{11}$ For example, the Nuclear Suppliers Group ("NSG") Guidelines are a set of export control guidelines governing the transfer of nuclear materials between states. ${ }^{12}$ The NSG Guidelines are not themselves legally binding on states, which instead voluntarily adhere to them. However, the NSG Guidelines provide content to the legally binding-but vague-export-

9 Kenneth W. Abbott and Duncan Snidal, Hard and Soft Lap in International Govemance, 54 Intl Org $421,422(2000)$.

10 See generally Kal Raustiala, Form and Substance in Intermational Agreements, 99 Am J Intl L 581(2005) (favoring a distinction based on legality).

11 We recognize that this definition does not clearly distinguish what we term soft law from what might be termed "political commitments." Is a promise made by a national leader in a public speech soft law or mere politics? What about an informal exchange of promises between national leaders? We have disagreed about whether an analytically clear distinction between soft law and purely political agreements is possible. Compare Guzman, How International Law Wortes (cited in note 5), with Meyer, 32 Fordham Intl L J (cited in note 4). However, our focus is on the role of soft law as promulgated by international tribunals, and so we can put this issue to one side.

12 Nuclear Suppliers Group Guidelines, available online at <http://www.nuclearsuppliersgroup. org/guide.htm> (visited Dec 5, 2008). 
control obligation established by the Nuclear Nonproliferation Treaty, ${ }^{13}$ and in any event are incorporated into domestic law in the US by statute and regulation. ${ }^{14}$

From a functional standpoint, the Article's definition recognizes that hard law, soft law, and purely political agreements lie on a continuum in terms of their ability to generate compliance. ${ }^{15}$ This is so because these different doctrinal categories represent signaling devices, allowing states to make different pledges of reputational capital. A more serious pledge of reputational capital, such as that involved in signing a treaty, increases both the reputational sanction and the likelihood of retaliation in the event of violation, and thus increases the probability of compliance. A soft-law agreement is a somewhat less serious pledge of a state's reputational capital because the obligation created is not legally binding. Purely political arrangements are the least effective, all else equal, because in making such an agreement a state pledges none of its reputation for compliance with legal obligations. The difference between these categories is in the magnitude of the incentive to comply. Doctrinal distinctions, in other words, are functional signals about future behavior.

Of course, states have other methods of inducing compliance that are not related to the specific type of legal agreement. Retaliatory sanctions, for example, can generate compliance by punishing violators. These sanctions are more likely when a state has entered into a more serious commitment because the sanctioning state has more reason to pursue a reputation for punishing violators of hard-law commitments. Nevertheless, retaliation can serve to promote compliance with weaker commitments as well-indeed, the threat of retaliation can influence state behavior even in the absence of any sort of consensual commitment. Retaliatory sanctions, however, are costly to the party imposing them and so the threat of such sanctions often lacks credibility. ${ }^{16}$ This is especially (though not uniquely) true in the context of multilateral commitments because would-be retaliating states have an incentive to free ride on the retaliatory efforts of others. Similarly, while some forms of cooperation can be sustained by the threat of reciprocal noncompliance, reciprocity's effectiveness is greatly reduced in the context of multilateral commitments or where obligations

13 Meyer, 32 Fordham Intl L J at 2 (cited in note 4).

14 The United States's export-control obligations are codified in the Arms Export Control Act, 22 USC $\$ 2778$ (2000), and the International Traffic in Arms Regulations, 22 CFR $\$ 120-30$ (2008).

15 Guzman, How Intemational Law Works at 211-18 (cited in note 5).

16 Id at 46-49. Where multiple states have an incentive to enforce an obligation, imposing retaliatory sanctions also suffers from a collective-action problem. The sanctions are a public good, and thus each state has an incentive to hold back enforcement, hoping other states will bear the cost that produces the collective benefit. 
are not reciprocal. ${ }^{17}$ Reputational sanctions, however, have the great advantage of being costless to impose. They are the result of a purely self-interested observational process: when a state observes another state violating a legal obligation, the observing state updates its expectations of when the violating state will honor its commitments. A reputation for honoring one's commitments is valuable to states because it allows them to enter into agreements in which their cooperative partners can rely on their behavior. The ability to more accurately rely on compliance, in turn, may allow states to extract valuable concessions on substantive parts of the agreement-in effect, cooperative partners will be willing to yield on substantive terms because they are relatively more confident they will get what they bargain for.

\section{B. Why States Choose Soft Law}

A lively debate exists among scholars as to why states choose to forego the benefits of creating legally binding obligations, and instead structure agreements as nonbinding. Some scholars, for example, have argued that soft law-precisely because it is nonbinding-must be easier to renegotiate in the event of changed circumstances. ${ }^{18}$ Others have posited that as a matter of domestic law, soft-law agreements are easier to conclude than hard-law agreements. ${ }^{19}$ Unlike treaties, for example, which in the US require the advice and consent of the Senate, softlaw agreements are thought to be subject to fewer checks domestically.

The mere fact, however, that an agreement is soft does not necessarily mean either that states will have an easier time renegotiating it or that the domestic costs of creating a legal obligation are less. With respect to the former, soft-law obligation's are the product either of negotiation between states or the work of an international organization, such as a tribunal-just as hard law is. Thus, there is no particular reason to think that states parties will be able to amend soft-law agreements any more easily than they can amend hard-law agreements. To return to a prior example, the NSG is comprised of forty-five states and operates by consensus. ${ }^{20}$ Thus, as a purely formal matter, amending the NSG Guidelines can

17 Here we have in mind obligations that are truly multilateral, as distinct from bilateral commitments made in the context of a multilateral agreement. An example of the former would be the Kyoto Protocol-the commitments made by parties to the treaty are made to all other parties. An example of the latter might be the World Trade Organization ("WTO') Agreements-though this is a set of multilateral agreements, the commitments are, at their core, bilateral. See Guzman, How Intemational Law Works at 42-45 (cited in note 5).

18 See Abbott and Snidal, 54 Intl Org at 444 (cited in note 9); Charles Lipson, Wby Are Some Intermational Agreements Informal?, 45 Intl Org 495 (1991).

19 See Lipson, 45 Intl Org at 500 (cited in note 18).

20 Meyer, 32 Fordham Intl L J at 20 (cited in note 4). 
be as difficult as amending a treaty that has forty-five members. ${ }^{21}$ Each member can veto any proposed changes to the status quo.

The view that soft-law obligations are less costly to create as a matter of domestic law almost certainly has some validity. That said, the argument often overstates the role of domestic law in the choice between hard and soft law. The argument focuses on American law, and the first thing to note is that notwithstanding the constitutional requirement that two-thirds of the Senate concur in the creation of treaties, ${ }^{22}$ the President does not seek the consent of the Senate in this form for most documents that create binding international legal obligations for the United States. ${ }^{23}$ The more common way in which the US enters into obligations is through congressional-executive agreements, which require a simple majority in both Houses of Congress. Such agreements are treaties for the purposes of international law and are binding on the US. ${ }^{24}$

Furthermore, parliamentary systems of government often lack even these checks on the government's ability to create international legal obligations. While a particular legal obligation may generate political opposition, as a matter of constitutional law the government often can, if it chooses, simply enter into a binding agreement without, as a matter of law, having to seek the blessing of any separate governmental institution.

Finally, because soft-law agreements are often given effect through domestic statute or regulation, they frequently require the approval of a domestic legal entity. For example, after the Basel Committee negotiated Basel II, a revised set of rules governing national capital-adequacy standards for banks, the new standards still had to be vetted through notice-and-comment procedures before they had any legal effect within the US. ${ }^{25}$ Thus, while the domestic-law explanation is almost certainly a part of the story, it is unlikely to explain the full spectrum of soft-law instruments.

A third explanation for the use of soft law relies on risk aversion. The notion is that states sometimes prefer soft-law agreements because they reduce the costs of exit. That is, states may opt for soft law rather than hard law in order to

21 Id.

22 US Const, art II, $₫ 2$.

23 John C. Yoo, Laiss as Treaties?: The Constitutionality of Congressional-Executive Agreements, 99 Mich L Rev 757, 767 (2001).

24 Moreover, the executive branch can, under certain circumstances, enter into "sole executive agreements" that are treaties under international law but do not require any congressional approval.

25 Federal Reserve Board, Joint Press Release, Banking Agencies Announce Publication of Revised Capital Framework and Describe U.S. Implementation Efforts (June 26, 2004), available online at <http://www.federalreserve.gov/boarddocs/press/bcreg/2004/20040626/> (visited Dec 5, 2008). 
preserve flexibility in making future decisions. We have two main objections to this perspective. First, it is not clear that soft law-as compared to hard lawreduces the risk to which states are exposed. A soft-law agreement is more easily ignored, so it is both easier for a state to ignore its own commitments-thereby reducing its risk-and more likely that a state's counterparty will behave inconsistently with the soft-law commitment. This added uncertainty about the behavior of other states increases the risk that states face. Moreover, there is no particular reason to think that the reduction in risk resulting from one's own flexibility necessarily outweighs the increased risk resulting from counterparties' increased flexibility.

Second, though it is commonplace to model states as risk averse in the international-relations literature, when dealing with international legal commitments it is more appropriate to model states as risk neutral. It is possible that, as a general matter, states themselves are risk neutral-meaning that they are indifferent between a given payoff with certainty and a lottery with the same expected payoff. Even if they are risk averse, however, they are likely to behave in a risk-neutral fashion with respect to their legal commitments (including softlaw commitments). This is so because they are well diversified in such commitments. A given state might have thousands of legal obligations at any one time, and those obligations span a wide range of subject areas-from trade to environment to human rights to broadcasting. What the state cares about, of course, is the aggregate payoff from all of its commitments. ${ }^{26}$ Diversification across international commitments serves to eliminate idiosyncratic risk in just the same way that diversification across financial instruments does. So while the state may be risk averse with respect to its aggregate payoff, it will behave in a risk-neutral fashion with respect to individual commitments. In other words, the state will seek to maximize the expected payoff from such commitments. ${ }^{27}$

When one examines the above explanations of soft law carefully, they are unsatisfactory. Soft law, therefore, remains a puzzle. In past writing we have each advanced theories of soft law that explain much of the variation in legal formality that we observe in international agreements.

Guzman has argued that states often forego the benefits of the greater credibility associated with binding legal agreement because credibility has associated costs. ${ }^{28}$ An increase in credibility-or in other words an increase in the reputational sanction associated with violating an obligation-is, in effect, a

26 This argument is the same whether the objectives of the state are some measure of general welfare or the private interests of government leaders.

27 See Guzman, How Intemational Law IVorks at 122-26 (cited in note 5).

28 See generally Andrew T. Guzman, The Cost of Credibility: Explaining Resistance to Interstate Dispute Resolution Mechanisms, 31 J Legal Studies 303 (2002). 
double-edged sword. On the one hand, a higher cost of violation creates a stronger incentive to perform one's obligation, and thus generates some marginal benefit in terms of compliance. On the other hand, when there is a violation, the expected loss to the parties will be larger. This problem is exacerbated by the fact that a reputational loss to the violating party is not offset by a corresponding benefit to the non-violating party. Thus, increasing the marginal reputational sanction for violation by, for example, moving from a soft to a hard legal obligation has the effect of increasing the expected loss should a violation occur, while at the same time reducing the number of expected violations. In creating an obligation, states will seek to set the expected marginal benefit from an increase in credibility, or the benefit from the marginally deterred violations, equal to the expected marginal cost-an increase in the negative-sum sanction for those violations that are not deterred. ${ }^{29}$ The result is that in many cases, the marginal costs associated with making an agreement legally binding will be too great to justify.

Meyer has proposed an explanation that fits a different set of soft-law instruments. He explains that soft law acts as a form of delegation to particular states to unilaterally revise the content of soft legal obligations. ${ }^{30}$ This theory is based on the fact that there are at least two distinct reasons why a state may violate an obligation. First, a state may breach its obligations opportunistically; it may see the chance to seize an immediate benefit at the expense of cooperative partners. Alternatively, states may violate an obligation because circumstances have changed since the obligation was created and the obligation itself has become individually, and very often globally, suboptimal. In the latter scenario, the violating state is not necessarily seeking to benefit at its cooperative partners' expense. Rather, it is hoping to establish a new standard of conduct to which its cooperative partners will voluntarily adhere. In some situations, of course, establishing those new standards may be accomplished through explicit renegotiation. But renegotiation is costly, and in many cases can fail even when welfare-enhancing amendments are available. Renegotiation, after all, requires a Pareto-improving amendment to the agreement. Though in principle there always exist transfers sufficient to convert any agreement that increases overall welfare into a Pareto-improving arrangement, in practice such transfers may be frustrated by informational asymmetries, holdouts, and any number of other transaction costs. ${ }^{31}$ In such situations, international law's default rule of

29 Id.

30 Meyer, 32 Fordham Int L J at 22 (cited in note 4).

31 See, for example, Andrew Guzman and Beth A. Simmons, To Settle or Empanel? An Empirical Analysis of Litigation and Settlement at the World Trade Organization, $31 \mathrm{~J}$ Legal Studies 205, 213 (2002) (demonstrating that states find it more difficult to settle trade disputes when the issue in dispute 
unanimity stifles the evolution of law. And while voting rules that permit amendment with less-than-unanimous consent can reduce such transaction costs, they cannot eliminate them. Moreover, majoritarian voting rules can create the possibility of cycling majorities, itself a transaction cost that can offset benefits from nonunanimous voting by making it difficult to settle on any single Pareto-improving amendment. ${ }^{32}$

By reducing the cost of deviating from an obligation, however, soft law allows legal rules to evolve without the need for explicit renegotiation. A single state can unilaterally and publicly adopt a new legal norm, calculating that when presented with an alternative, other states will follow suit, and expectations as to what constitutes compliant behavior will adjust accordingly. And while the first state to act will absorb a reputational hit for violating existing obligations, all else equal, the size of that sanction will be reduced if the obligation is a soft oneand therefore the state's willingness to act as an entrepreneur for new legal norms will be increased. Of course, encouraging this type of legal entrepreneurship is not always desirable. Soft law increases the likelihood of both opportunistic legal revision-that which benefits the legal entrepreneur but is not globally optimal-as well as legal revisionism that improves global welfare. To ensure that the benefits of the latter outweigh the former, soft law is more narrowly appropriate when uncertainty over the future efficiency of legal rules is high and a state (or small group of states) has a particularly strong interest in the rules governing a particular type of conduct. From an ex ante perspective, other states expect the particularly interested state to update the rules as circumstances change. They, in effect, have delegated to that state the functional ability to legislate on their behalf. Under this view of soft law, states are trading off the procedural equity inherent in changing legal rules only through explicit renegotiation against the greater efficiency of legal rules that can result when renegotiation is not stymied by the unanimity rules that flow from sovereign equality.

\section{INTERnAtional COMMON LAw}

In this Article we introduce a third explanation of soft law, specifically the soft law made by international tribunals. We call the relevant legal pronouncements "international common law" to reflect the fact that they are created by tribunals-much like common-law rules. Unlike common law,

has an "all-or-nothing" feature than when it is more of a continuum, suggesting that states find it difficult to construct compensatory transfers).

32 See Neil Siegel, Intransitivities Protect Minorities: Interpreting Madison's Theory of the Extended Republic 62 (2001) (unpublished $\mathrm{PhD}$ dissertation, University of California, Berkeley) (on file with the University of California, Berkeley Library). 
however, these rules lack the binding force of law. We believe this new theory complements our prior work in the sense that the three theories taken together have the potential to explain a great deal of the soft law that we observe. We believe, in other words, that different instances of soft law are explained by different forces, but that this new theory accounts for a large share of what the prior theories left unexplained.

The basic notion of international common law is straightforward. When international tribunals speak they perform at least two distinct functions. First, they resolve the dispute before them (or at least attempt to do so). The decision of a tribunal that has proper jurisdiction to hear a dispute is often legally binding for the parties to the litigation in the sense that the legality of state conduct is judged, and the states involved are obliged to end their dispute on the terms provided by the tribunal unless they agree on some alternative. Most studies of international tribunals focus on this function: their role in resolving disputes.

We are interested in a second function performed by the decisions of international tribunals. Though judgments of international tribunals formally have no binding effect on states that are not party to the dispute, and the principle of stare decisis does not apply in this context, they nevertheless impact perceptions about the content of international law and the attitudes and actions of states. One cannot, for example, discuss the international law governing intervention in another state's internal conflict without considering the ICJ's Nicaragua case. ${ }^{33}$ Similarly, understanding World Trade Organization ("WTO") law relating to health and safety measures requires analysis of the $E C-$ Hormones ruling, among others. ${ }^{34}$ Indeed, tribunal rulings on one bilateral investment treaty ("BIT") are central to understanding the law that applies in entirely different BITs between different parties.

The benefits of using tribunals to promulgate international common law are clear-doing so allows the law to be interpreted, adapted, and even changed without the need to achieve unanimity among affected states. ${ }^{35}$ International common law, then, can be seen as another strategy to overcome the status quo bias that is inherent in "hard" international law and that can frustrate attempts to

33 Case Conceming Military and Paramilitary Activities in and against Nicaragua (Nicar v US), 1986 ICJ 14 (June 27, 1986).

34 World Trade Organization, Report of the Appellate Body, EC-Hormones, WT/DS26/AB/R, WT/DS48/AB/R (Feb 13, 1998), available online at <http://www.wto.int/english/tratop_e/ dispu_e/disp_settlement_cbt_e/a1s1p1_e.htm> (visited Dec 5, 2008).

35 We recognize that it is an overstatement to say that state consent is required for all binding legal rules. Rules of customary international law and jus cogens norms can arise without the consent of all affected states. See generally Andrew T. Guzman, Saving Customary Intemational Law, 27 Mich J Intl L 115 (2005). See also Laurence R. Helfer, Nonconsensual International Lavmaking, 2008 U Ill L Rev $71,79-90$ (discussing forms of international lawmaking that do not require explicit consent). 


\section{Cbicago Journal of International Lan}

achieve value-increasing legal change. ${ }^{36}$ A tribunal is given some authority to opine on a legal dispute and the resulting statement by the tribunal becomes part of the international law discourse. Somewhat paradoxically, the fact that the statement from the tribunal lacks formal legal effect can actually expand the reach of soft legal standards, as discussed below.

Understanding the relevance of international common law requires an understanding of compliance and the impact of international law that goes beyond traditional doctrinal approaches. We are interested here in tribunals that do not have jurisdiction over-or put differently, lack the explicit consent of all affected states, and whose statements and actions therefore do not fit within the conventional categories of binding international law. A formalist approach might conclude, therefore, that we are not discussing international law at all. In talking about soft law generally, for example, Weil states that obligations fitting the definition of soft law used in this Article "are neither 'soft law' nor 'hard law': they are simply not law at all." of international law that states cannot be bound without their consent. ${ }^{38}$ Where treaties are concerned, the process of consent is explicit: states negotiate, sign, and ratify treaties. Similarly, the opinio juris requirement of customary international law, as traditionally understood, is somewhat similar to a consent requirement - states must believe that a rule of international law binds them, and through the use of the persistent objector doctrine can disclaim being bound by a rule. ${ }^{39}$

We are interested, however, in more than simply the traditional and formal definitions of international law. We are interested in how international legal rules (defined broadly to include more than simply those that are "binding" under international law) affect state behavior. This leads to the question why rules affect behavior, and which ones do so.

36 Another way to address the issue is through soft law created through international agreements or by international entities other than states such as the Organization for Economic Cooperation and Development or the International Labor Organization.

37 Prosper Weil, Towards Relative Normativity in Intermational Law, 77 Am J Intl L 413, 414-15 n 7 (1983).

38 See, for example, Louis Henkin, International Law: Politics, Values and Functions, 216 Recueil des Cours 9, 27 (Martinus Nijhoff 1989) ("[A] State is not subject to any external authority unless it has voluntarily consented to such authority."); The Case of the S.S. Lotus (Fr v Turk), 1927 PCIJ (ser A) no 10 at 18 (Sept 7, 1927) ("The rules of law binding upon States therefore emanate from their own free will.').

39 Andrew T. Guzman and Timothy L. Meyer, Customary International Law in the 21st Century, in Russell A. Miller and Rebecca M. Bratspies, eds, Progress in International Law at 197, 205 (Martinus Nijhoff 2008). See also Guzman, 27 Mich J Intl L at 141-46 (cited in note 35) (explaining that consent is not necessary for a state to be affected by customary international law). 
As we have said, the primary mechanisms that cause international law-both hard and soft - to be effective are reputation, reciprocity, and retaliation. ${ }^{40}$ Each of these is affected by the perceptions of observing states. In other words, the costs of an action are related to the question of whether observing states believe that an international legal commitment has been violated. ${ }^{41}$ Thus, the expectations and beliefs of other states are critical to compliance decisions. Consent plays an important role in the shaping of expectations and beliefs, particularly where explicit agreements are concerned, but it is by no means the only relevant factor. A treaty that codifies universally applicable customary norms, such as the Vienna Convention on the Law of Treaties or the Vienna Convention on Diplomatic Relations, can shape expectations about the specific content of those norms - even as applied to states that do not sign the treaty. ${ }^{42}$ Similarly, establishing an international tribunal that has jurisdiction to rule on the content of customary international law can create a forum in which the precise content of obligations is clarified (in a nonbinding way) and information about violations is produced. ${ }^{43}$ Thus, for example, the ICJ decision in the Nicaragua case speaks to the rules governing the use of force and intervention. One could safely argue that the ICJ decision itself is not hard law (except with respect to the resolution of that particular dispute), but one would have real difficulty defending the claim that it has no bearing on the legality of state conduct. The way in which this soft law pronouncement by a tribunal (what we call international common law) comes to affect the costs and benefits of state behavior is through the expectations of other states. The ICJ decision is taken as an authoritative and neutral statement about the law. Though nonbinding, it influences states' expectations. Future conduct that is inconsistent with the ICJ's perspective is more likely to be considered illegal and, therefore, is more likely to lead to retaliation, reciprocal non-compliance, or reputational sanctions.

The need for international common law stems from limitations imposed by doctrine on the development of legal rules and expectations. Where treaties are concerned, states can, of course, always veto a set of legal rules as applied to them. Where custom is concerned, the organic, decentralized way in which custom forms makes it a poor policy instrument for states. How, then, can states allow international legal rules to evolve and develop?

\footnotetext{
40 See note 5.

41 Throughout this Article, we refer to both hard-law and soft-law commitments as "legal" commitments. This reflects our view that there is no stark distinction between hard and soft law and that both operate through the same fundamental mechanisms of reputation, reciprocity, and retaliation.

42 Guzman and Meyer, Customary Intermational Law in the 21 st Century at 211 (cited in note 39).

43 Id at 214-15.
} 
Imagine, for example, that a group of states (perhaps all states) face a common problem. It may be possible to design a formal treaty to resolve the problem, but this requires that every state joining the treaty be made better off. In many instances advancing the welfare of the group requires that some states bear net costs, and those states can be expected (understandably) to refuse to participate.

Where agreement on a treaty (or even a soft-law agreement) is impossible, and where existing customary norms are inadequate, states can adopt a different strategy to promulgate new norms aimed at constraining state behavior. Specifically, they can delegate to a tribunal or other international or transnational entity the authority to make nonbinding statements about legal norms. Doing so takes distributional questions about who should bear costs out of the hands of individual states and places them in the hands of a neutral tribunal. In some circumstances, the decision to delegate to a tribunal can have a positive expected value for all states, despite the fact that everyone recognizes that when the tribunal acts, some of them will suffer net costs.

\section{Less Control, More VAlue}

From a rational design standpoint, such a delegation-choosing, in effect, to determine standards in a forum with a less powerful status quo bias (because the consent of all states is no longer required) -involves a tradeoff between the control states have over legal norms and the expected gains from legal developments.

Establishing a tribunal and giving it the authority to opine on the law necessarily involves a delegation of authority to that tribunal. In this sense, the creation of a tribunal involves some lessening of control by states-at least when taken collectively. ${ }^{44}$ The tribunal must have some limited ability to move away from the preferred legal standard of the states themselves if it is to be effective. To be sure, states will tolerate such a move only so long as, on balance, it remains in their interest to continue the delegation. Furthermore, depending on the structure of the tribunal, states can exert pressure in a variety of ways, and may have mechanisms of formal influence such as an oversight role or the ability to appoint representatives. ${ }^{45}$ Nevertheless, states must surrender the right to veto

44 It is difficult to say definitively whether creation of a tribunal lessens the control in the hands of an individual state, because no individual state can force a change in the legal rules. It is true that every state can veto a change in the hard law, but it cannot cause the law to change. A tribunal reduces the ability of the state to prevent changes, but it also increases the state's ability to bring about change through dispute resolution.

45 See generally Andrew T. Guzman, International Tribunals: A Rational Choice Analysis, $157 \mathrm{~Pa} \mathrm{~L} \mathrm{Rev}$ 171 (2008). 
the legal standards proposed by a tribunal and must accept that legal standards may move away from their preferred position.

In exchange, states are able to overcome the need for unanimity. Legal standards laid down by a tribunal affect all relevant states - not only those that have consented to the jurisdiction of the tribunal. The relevant legal rules, then, have a broader, if perhaps shallower, impact than they would if consent were required. ${ }^{46}$ Where a tribunal collects information and issues standards, for example, states are faced only with an ex post decision whether to comply. Though they can argue against the rule laid down by the tribunal, they cannot reverse the impact that the tribunal's statement has on state expectations and beliefs.

Importantly, even states that did not participate in the creation of a tribunal, or have not agreed to be subject to the tribunal's jurisdiction, can be impacted by a ruling. To see the logic of such an arrangement, consider the following brief example. A group of states wishes to establish standards governing conduct in a certain area. One possibility is a negotiated agreement among them. Under the "cost of credibility" thesis, such an agreement would take the form of a hard agreement if the marginal benefit in terms of expected violations deterred outweighed the marginal cost to the parties from sanctions for those violations that are not deterred; if not, then the agreement would be soft. Under the delegation thesis, if states are uncertain about the future optimality of the rules they can agree on in the present and about their ability to reach agreement again in the future, they will choose soft law; ${ }^{47}$ if they expect the factors affecting their present negotiations to be stable over time, they will choose hard law. Imagine, however, that negotiations are driven neither by the expected cost of future sanctions nor the expected cost of future renegotiation. Instead, the difficulty is accommodating all the parties in a single agreement. While the parties wish to

46 Michael Gilligan has demonstrated that where states need not choose identical policies under an international agreement, there is not necessarily a tradeoff between the breadth and depth of cooperation. See generally Michael J. Gilligan, Is There a Broader-Deeper Trade-Off in International Multilateral Agreements?, 58 Intl Org 459 (2004). Under this theory, making the jurisdiction of an international tribunal optional might seem a way to avoid the broader-deeper tradeoff. Only those relatively more committed states need accept the tribunal's jurisdiction. The theory presented in this Article, however, indicates that optional dispute-resolution provisions likely do not soften this tradeoff as much as Gilligan's theory might suggest. While only those states that submit to the jurisdiction of the tribunal allow for the possibility of an adverse legally binding ruling, all states are affected by the tribunal's actions. Thus, the difference between the obligations of the two groups of states is not as stark as it might appear to be at first blush.

47 This presumes, of course, that the expected efficiency gains outweigh any expected increase in opportunistic violations. See Meyer, 32 Fordham Intl L J at 21-31 (cited in note 4). 
coordinate their behavior, the distributional issues surrounding any precise agreement defeat a fully specified hard-law agreement among all parties. ${ }^{48}$

A solution is to create an agreement that is incompletely specified and a tribunal with the authority to resolve disputes under the agreement. The tribunal is given certain guidelines for resolving disputes but it is understood that some questions are being left unresolved in the agreement itself. Once these structures are in place, states can pursue complaints before the tribunal. Each case yields binding obligations for the parties to the dispute, but it also generates international common law that influences the expectations of all parties to the agreement. A concrete example of such an arrangement is the WTO Dispute Settlement Understanding, which creates a mandatory dispute-resolution system for WTO members. The WTO Dispute Settlement Body's rulings are binding on the states that are party to the litigation, but lack any more expansive binding legal effect. Nevertheless, its rulings are understood to fill in many of the gaps in the WTO's obligations. Indeed, the WTO makes readily available data on the disputes that come before the tribunal, suggesting that the tribunal's rulings - far from being limited in effect to the parties before it-are scrutinized by a broad audience and understood to clarify, albeit in a nonbinding way, the obligations of all WTO members.

The parties to the agreement can choose to disregard the international common law that emerges from the tribunal, but doing so carries costs because other states will perceive them to be failing to honor their soft-law commitments. If these costs are sufficiently high, even a state that would not have consented to a given norm ex ante will abide by it once it has emerged from a tribunal. Thus, the creation of nonbinding norms circumvents the need for ex ante agreement. The statements by the tribunal are a take-it-or-leave-it offer to states, which puts them in a different posture than they are in when negotiating.

Interestingly, because the tribunal speaks to the meaning of a background legal rule (for example, the substantive rules of a treaty), to the extent it influences a legal norm it does so for all states-not only those that favored the creation of a tribunal or that have submitted to its jurisdiction. The tribunal's statements, if they are effective, create a new default rule for all states subject to the underlying legal regime.

It is also worth mentioning that international common law, in contrast to hard law, is difficult to exit. A state can withdraw from a formal treaty, such as a jurisdiction-conferring optional protocol, should it find that the agreement no

48 A two-player version of this game is called the Battle of the Sexes, in which both players prefer to coordinate their behavior, but there is tension in their interests as to which particular outcome they coordinate on. 
longer serves its needs. ${ }^{49}$ It is much more difficult-and sometimes impossible - to withdraw from the influence of international common law. The US, for example, has withdrawn its consent to the compulsory jurisdiction of the ICJ.$^{50}$ This ensures that the US will not find itself a party in a dispute before the ICJ without some other consent to jurisdiction. It does not, however, protect the US from the international common law created by that court. Thus, for example, while the US is immune from the jurisdiction of the ICJ to hear a dispute based on the alleged harmful consequences of the American contribution to global climate change, the US would not be immune from the soft legal effects of an adverse ruling against another state charged with similar harmful actions. ${ }^{51}$

\section{The UN Human Rights CommitTee}

The UN Human Rights Committee illustrates precisely this type of international common law. The Committee was established by Article 28 of the ICCPR to monitor compliance with the terms of that agreement. ${ }^{52}$ The Committee consists of eighteen members who, although nominated by their home states, are elected and serve in their personal capacities. ${ }^{53}$ The Committee meets the definition of a tribunal because, unlike the NSG, which is composed of states themselves, the Committee members are formally independent of states. ${ }^{54}$

The Committee carries out its task of monitoring compliance in three ways. First, the ICCPR requires parties to report to the Committee on the steps they

49 Formally there are some treaties from which exit is not possible. See, for example, Vienna Convention on the Law of Treaties (1969), art 56, 8 ILM 1969. Nevertheless, a state wishing to withdraw from a treaty can, as a practical matter, achieve that result, though it may bear a cost for doing so.

50 See Letter from Secretary of State Schultz to the Secretary-General of the United Nations (Oct 7, 1985), in Department of State Letter and Statement Concerning Termination of Acceptance of ICJ Compulsory Jurisdiction, 24 ILM 1742, 1743 (Nov 1985).

51 See Shi-Ling Hsu, A Realistic Evaluation of Climate Change Litigation Through the Lens of a Hypothetical Lausuit, 79 U Colo L Rev 701, 726-27 (2008).

52 International Covenant on Civil and Political Rights and Optional Protocol, General Assembly Res No 2200 Supp No 16 at 52, 59, UN Doc A/6316 (1966) (entered into force Mar 23, 1976) ('ICCPR").

53 Id, art 28(3).

54 That being said, it should hardly come as a surprise that states have established selection procedures that allow them to exert substantial influence over the makeup of the Committee. In addition to nominating individuals to serve on the Committee, states elect the Committee members. Significantly, the ICCPR provides that a person may be renominated and reelected thus creating an incentive for Committee members to be mindful of the interests states have in their decisions. ICCPR, arts 29(3), 32(1). 
have taken to implement the obligations created by the ICCPR. ${ }^{55}$ The ICCPR specifically authorizes the Committee to "comment" on the reports and submit those "comments" to the states for their consideration. ${ }^{56}$ Second, the ICCPR permits states to declare their willingness to have their compliance with the ICCPR challenged by other member states. ${ }^{57}$ If the parties do not reach an amicable solution, the ICCPR authorizes the Committee to request information from the parties and requires it to issue a report on the dispute. ${ }^{58}$ Third, the Optional Protocol to the ICCPR allows states to permit individuals to lodge complaints about their human rights practices with the Committee. ${ }^{59}$ When a complaint is properly made, the Committee is authorized to receive information about the dispute from both the individual and the state concerned, and to formulate and express its "views" on the matter. ${ }^{60}$

The "views" and "comments" expressed by the Committee fit our definition of soft law and illustrate the attraction of international common law. They have no independent legal effect. ${ }^{61}$ Unlike a court's ruling on a dispute properly within its jurisdiction, a party is not legally bound by an adverse view of the Committee. Nevertheless, the views expressed by the Committee are not without indirect legal significance. Although nonbinding, the Committee's views elaborate on what is required by the ICCPR's legally binding obligations. The Committee's decisions are, in effect, a nonbinding gloss on the legal obligations contained in the ICCPR, rather than the distinct legal obligations that would arise from a binding ruling. Their nonbinding nature necessarily reduces their compliance pull, but at the same time also expands their ability to shape (admittedly weaker) expectations for states that, while party to the ICCPR, have not submitted to the Committee's jurisdiction.

Most important for the theory presented in this Article is the system of review established by the Optional Protocol. Although the Committee is established by the ICCPR itself, and thus at least all of the initial members of the ICCPR concurred in its creation, it is the individual petition system established by the Optional Protocol that has been most effective in developing a human rights jurisprudence. ${ }^{62}$ Notably, while the ICCPR has 162 parties, the Optional

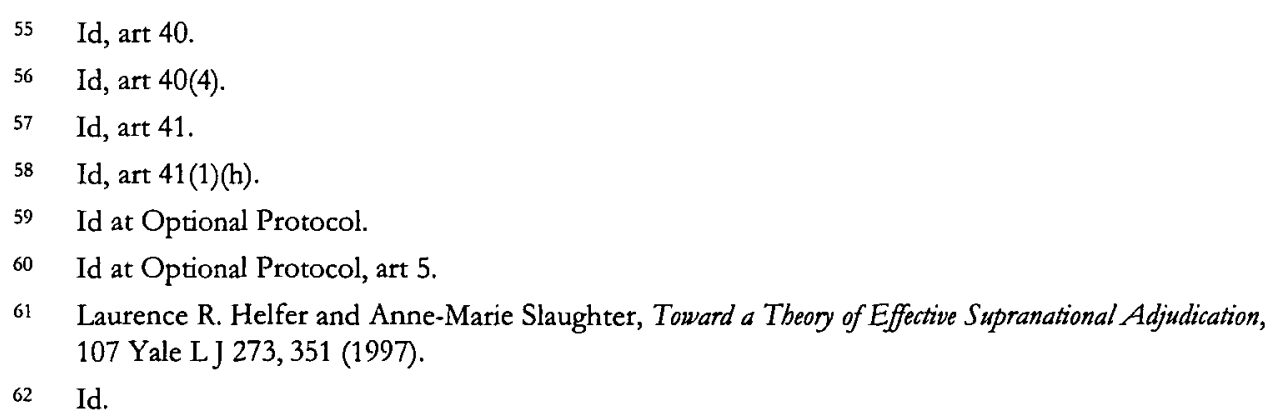


Protocol has only $111 .^{63}$ Thus, the Optional Protocol establishes the very type of institutional framework characteristic of international common law-a delegation by a subset of states of the power to announce soft legal standards applicable to a broader group of states. ${ }^{64}$

Consider, for example, one of the Committee's most famous decisions, Toonen v Australia. ${ }^{65}$ There, the Committee expressed the "view" that Tasmania's anti-sodomy laws violated the privacy and antidiscrimination provisions of the ICCPR. This view, of course, was nonbinding on Australia, but nevertheless has been seen as a contributing factor in the Australian government's decision to effectively preempt the Tasmanian law. ${ }^{66}$ But the Toonen decision's consequences did not stop with Australia. In 1995, a year after the Toonen decision, the Committee expressed concern in its consideration of the American report made under Article 40 of the ICCPR "at the serious infringement of private life in some states which classify as a criminal offence sexual relations between adult consenting partners of the same sex carried out in private, and the consequences thereof for their enjoyment of other human rights without discrimination."${ }^{.67}$ This statement was a direct effort by the Committee to extend the reach of its Toonen decision to other contexts-in this case, contexts in which it lacked jurisdiction to hear individual disputes. The US, after all, has not signed the Optional Protocol to the ICCPR, and thus cannot have its practices challenged by individuals. ${ }^{68}$ Nevertheless, as evidenced by its comments on American practices, the Committee, and likely other states as well, understood the Toonen decision to provide clarification of the ICCPR's binding obligations. The Toonen

63 See Office of the United Nations High Commissioner for Human Rights, Optional Protocol to the International Covenant on Civil and Political Rights (Dec 16, 1966), available online at <http://www2.ohchr.org/english/bodies/ratification/5.htm> (visited Dec 5, 2008).

64 In the Committee's case, it is its own jurisdiction that most immediately effects the delegation. Simply creating a tribunal, after all, does not allow it to pronounce legal rules; a tribunal requires jurisdiction. Broadening (or contracting) a tribunal's jurisdiction is thus a way to expand (or limit) a tribunal's ability to make international common law.

65 Nicbolas Toonen v Australia, Commun No 488/1992, UN Doc CCPR/C/50/D/488/1992 I 7.8 (1994), available in ICCPR: Selected Decisions of the Human Rights Committee under the Optional Protocol, Vol 5, UN Doc CCPR/C/OP/5/133 (2005).

66 See Emma Mittelstaedt, Comment, Safeguarding the Rigbts of Sexual Minorities: The Incremental and Legal Approaches to Enforcing Intermational Human Rights Obligations, 9 Chi J Intl L 353, 386 n 13 (2008).

67 Consideration of Reports Submitted by States Parties under Article 40 of the Covenant, UN GAOR Hum Rts Commn, 53d Sess, UN Doc CCPR/C/79/Add 50 (1995), available online at $<$ http://www.unhchr.ch/tbs/doc.nsf/0/b7d33f6b0f726283c12563f000512bd1?Opendocument > (visited Dec 5, 2008).

68 See Office for the United Nations High Commissioner for Human Rights, Status of Ratification of the Principal International Human Rights Treaties at 11, available online at <http://www.unhchr. $\mathrm{ch} / \mathrm{pdf} /$ report.pdf $>$ (visited Dec 5, 2008). 
decision, in other words, is itself a soft-law obligation piggybacking on the hardlaw obligations of the ICCPR.

Two final distinctions are worth mentioning when discussing the design of international tribunals. First, tribunals influence state behavior in multiple ways. This Article has been concerned with tribunals' role as the creators of international common law, an essentially lawmaking function. But of course, tribunals also provide a monitoring function, creating information about violations. The analytical distinction between these two functions is important. While states can avoid creating additional information about their possible violations of international law by refusing to submit to a tribunal's jurisdiction, as the US has done with the Committee, they cannot escape the nonbinding expectations about conduct shaped by the international common law.

Second, the decision whether to make an international tribunal's decisions binding on the parties to a dispute will, for the most part, be determined by considerations other than the effect of the international common law, such as, for example, the cost of credibility. After all, whether a decision is binding on the parties before it has no direct effect on its nonbinding effect on other parties. Note, however, that the success of an international common-law regime does depend to some extent on the success of the delegation; in other words, a tribunal must have a broad enough jurisdiction to warrant states taking into consideration its rulings when forming their expectations about what constitutes compliant behavior. Making a tribunal's rulings binding may cause states to avoid submitting to the tribunal's jurisdiction, and therefore prevent the tribunal from having a sufficiently broad jurisdiction to perform its common-law functions. This suggests that analyzing tribunals that lack any binding authority, such as the Committee, by comparing them to human rights tribunals with authority to issue binding rulings, such as the European Court of Human Rights, runs the risk of ignoting differences in the institutional and political frameworks each was designed to address. In environments in which participation and compliance are already likely to be low, nonbinding obligations may be the best way to increase tine size of the tribunal's jurisdiction-and therefore the size and effectiveness of the delegation.

\section{CONCLUSION}

The growing use of both international tribunals and soft law has underlined the incredible variation in legal institutions that states have deployed to govern their conduct. Traditional international legal scholarship tends to cabin these phenomena by treating them as discrete, and sometimes antagonistic, trends. On this view, the explosion of international tribunals reflects an increased commitment to legalization, while soft law presents a challenge to the legalization trend that is assumed to be beneficial to 
international cooperation. But this dichotomy is illusory. As we have explained both in this Article and in prior work, soft law can in some situations suit states' cooperative goals better than hard law. Moreover, because international tribunals are not generally bound by the principle of stare decisis, their rulings are in fact a form of soft law.

Indeed, it is as soft law that the decisions of international tribunals have their broadest effect; the decisions of international tribunals at most bind the parties to the dispute before the tribunal on the facts of the case, but their nonbinding interpretation of hard legal obligations affects the legal expectations of all states subject to the underlying obligation. The fact that this is so allows particularly committed states to bind relatively less-committed states through the creation of an international tribunal. The grant of jurisdiction is, in effect, a delegation to the international tribunal to create an international common law. Thus, while states can escape the monitoring function of an international tribunal by refusing to consent to its jurisdiction, they cannot escape the soft legal expectations created by the tribunal's jurisprudence. In this way, states are able to partially surmount the difficulties created by the traditional requirement of state consent. International tribunals create an international common law that can evolve without the need for the consent of all affected states, thus creating potential welfare gains, if sometimes at the expense of the principle of sovereignty. 


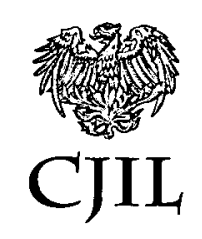

HeinOnline -- 9 Chi. J. Int'1 L. 536 2008-2009 